\title{
Characterization of Aeromonas sobria TAP13 pili: a possible new colonization factor
}

\author{
MASAAKI IWANAGA $^{1,2 *}$ and AKIRA HoKAMA ${ }^{1}$ \\ ${ }^{1}$ Department of Bacteriology, and ${ }^{2}$ Research Institute of Comprehensive Medicine, University of the Ryukyus, \\ School of Medicine, 207 Uehara, Nishihara, Okinawa 903-01, Japan
}

(Received 24 March 1992; accepted 26 May 1992)

\begin{abstract}
Pili of Aeromonas sobria TAP13 were purified and characterized. The molecular mass of the pilin was estimated to be about $23 \mathrm{kDa}$ by SDS-PAGE. The TAP13 pili were immunologically different from $A$. sobria Ae1 pili and $A$. hydrophila Ae6 W pili as previously reported, nevertheless all three had indistinguishable morphology and shared a high degree of homology in their N-terminal amino acid sequences. Strain TAP13 and its purified pili did not agglutinate human, rabbit or sheep erythrocytes. However, they adhered to rabbit intestine. Organisms pretreated with the Fab fraction of an antipilus antibody failed to adhere to rabbit intestine, and organisms did not adhere to intestine pretreated with purified pili. These results suggest that the pili are a colonization factor of A. sobria TAP13 for the rabbit intestine.
\end{abstract}

\section{Introduction}

Aeromonas species are important human enteropathogens (Daily et al., 1981; Moyer, 1987; Janda, 1991). The generally accepted mechanisms by which enteropathogens cause diarrhoeal diseases are initial adhesion to the intestinal epithelium, colonization, and secretion of toxins. Various factors associated with aeromonad virulence, such as enterotoxins, haemolysins, adhesive ability, and invasive ability, have been reported (Cahill, 1990; Pazzaglia et al., 1990; Gray et al., 1990; Ascencio et al., 1991); however, their pathogenic role needs further assessment. Especially, details of the adherence mechanism(s), including identification of colonization factors and their receptors, are not yet fully understood. Various bacterial pili have been shown to be colonization factors (Krogfelt, 1991); therefore, studies on identification of colonization factors have initially focused upon pili. Among Aeromonas spp., one type of $A$. sobria pili and five types of $A$. hydrophila pili have been purified so far (Sato et al., 1989; Honma \& Nakasone, 1990; Ho et al., 1990; Hokama et al., 1990; Hokama \& Iwanaga, 1991). These studies have shown that $A$. sobria Ael pili and $A$. hydrophila Ae6 W pili are colonization factors for the intestine as well as haemagglutinins, and demonstrated the possible presence of other colonization factors in

* Author for correspondence. Tel. (098) 8953331 ext. 2287; fax (098) 8952951.
Aeromonas spp. This paper describes the purification and characterization of a type of $A$. sobria pili different from Aeromonas pili reported previously, including the adhesive properties of the organism and the isolated pili.

\section{Methods}

Bacterial strains. A. sobria TAP13, isolated from a patient with diarrhoea in Thailand, was used. A. hydrophila Ae6 and A. sobria Ae1, reported previously (Hokama et al., 1990; Hokama \& Iwanaga, 1991), were used for comparison. Other organisms stocked in our laboratory were used when necessary.

Culture conditions. The organisms, subcultured on a nutrient agar plate, were inoculated into $40 \mathrm{ml}$ tryptic soy broth (TSB, Difco) in a $100 \mathrm{ml}$ Erlenmeyer flask and cultured without shaking at $37^{\circ} \mathrm{C}$ for $12 \mathrm{~h}$. A $5 \mathrm{ml}$ portion of this culture was inoculated into $500 \mathrm{ml}$ of fresh TSB in a 3 litre Erlenmeyer flask and subsequently cultured at $37^{\circ} \mathrm{C}$ for $12 \mathrm{~h}$ with reciprocal shaking.

Purification of pili. The organisms harvested from 2 litres of culture were suspended in $60 \mathrm{ml} 50 \mathrm{~mm}-\mathrm{Tris} / \mathrm{HCl}$ buffer, $\mathrm{pH} 7.4$. This suspension was agitated in a Biomixer (Nihon Seiki) for $10 \mathrm{~min}$ and was then stirred with a magnetic stirrer for $2 \mathrm{~h}$ to detach pili from the cells. After centrifugation at $26000 \mathrm{~g}$ for $30 \mathrm{~min}$, the supernatant was filtered through a $0.45 \mu \mathrm{m}$ pore-size membrane. The filtrate was mixed with solid ammonium sulphate ( $20 \%$ saturation). After $1 \mathrm{~h}$ incubation at $4{ }^{\circ} \mathrm{C}$, the mixture was centrifuged at $26000 \mathrm{~g}$ for $30 \mathrm{~min}$. The pellet was suspended in Tris/ $\mathrm{HCl}$ buffer, and the suspension $(0.5 \mathrm{ml})$ was layered on top of a $9.0 \mathrm{ml}$ sucrose gradient prepared by layering $1.5 \mathrm{ml}$ of $60,50,40,30,20$ and $10 \%(\mathrm{w} / \mathrm{w})$ sucrose in Tris $/ \mathrm{HCl}$ buffer. This gradient was centrifuged at $152000 \mathrm{~g}$ for $16 \mathrm{~h}$ at $4{ }^{\circ} \mathrm{C}$. Fractions of $0.2 \mathrm{ml}$ were taken from the top to the bottom; each fraction was 
examined for purity by SDS-PAGE and electron microscopy. Fractions with pili were pooled, concentrated, and dialysed against $\mathrm{Tris} / \mathrm{HCl}$ buffer. This preparation was regarded as purified pili. For comparison, $A$. hydrophila Ae6 W pili and $A$. sobria Ael pili were purified as reported previously (Hokama et al., 1990; Hokama \& Iwanaga, 1991).

Electrophoresis. SDS-PAGE was performed by the method of Laemmli (1970). Proteins solubilized in sample buffer were stacked in $4 \%(w / v)$ acrylamide and separated in $13 \%$ acrylamide.

Electron microscopy. Cultured cells and purified pili were negatively stained with $4 \%(\mathrm{w} / \mathrm{v})$ uranyl acetate on carbon-coated Formvar grids and observed with a JEM 2000EX transmission electron microscope. Organisms adherent to rabbit intestinal villi were observed with a Hitachi S450 scanning electron microscope. The samples were prepared as described previously (Nakasone \& Iwanaga, 1987).

Immunological studies. Western blotting was performed as described by Towbin et al. (1979) to determine immunological cross-reactivity among TAP1 3 pili, Ael pili and Ae6 W pili. The agglutination titres of the nonimmunized rabbit serum and the antipilus antiserum were less than $\times 2$ and $\times 1024$, respectively, as examined by the test-tube dilution method; a 1:400 dilution of each serum was used in the reaction to blotted proteins. The specificity of the antiserum was also confirmed by electron microscopic immunogold labelling. Briefly, organisms on Formvar grids were reacted with a $1: 100$ dilution of the antipilus antiserum, and then exposed to a 1:20 dilution of colloidal gold particles $(15 \mathrm{~nm})$ conjugated to protein A (E-Y Labs). The grids were negatively stained with $4 \%$ uranyl acetate.

The adhesive properties of purified pili to the rabbit intestinal epithelium were examined immunohistochemically as described previously (Hokama et al., 1990). Briefly, pieces of formalin-fixed intestine were incubated in the purified pilus suspension $\left(300 \mu \mathrm{g} \mathrm{ml}^{-1}\right)$ at $30^{\circ} \mathrm{C}$ for $30 \mathrm{~min}$, and then washed vigorously in $\mathrm{Krebs}-\mathrm{Tris}-\mathrm{Ringer}$ buffer (KRT: $128 \mathrm{~mm}-\mathrm{NaCl}, 5 \cdot 1 \mathrm{mM}-\mathrm{KCl}, 1.34 \mathrm{~mm}-\mathrm{MgSO}_{4} \cdot 7 \mathrm{H}_{2} \mathrm{O}$, $2.7 \mathrm{~mm}^{-\mathrm{CaCl}_{2}}, 10 \mathrm{~mm}$-Tris/HCl buffer, $\mathrm{pH} \mathrm{7.4).} \mathrm{As} \mathrm{a} \mathrm{control,} \mathrm{the}$ intestinal sample was incubated in KRT buffer without the pili, and then all intestinal pieces were treated equally. The tissues were prepared for routine histological examination. Immunohistochemical reactions with antipilus rabbit serum, horseradish-peroxidase-conjugated anti-rabbit IgG goat IgG (Organon Teknika), and diaminobenzidine (Sigma) for enzymic colour development were done on glass slides by routine procedures.

The distribution of the pilus-related antigen in 98 other Aeromonas strains was examined by the test-tube agglutination test with antipilus antiserum. The strains were cultured in TSB for $12 \mathrm{~h}$ at $37^{\circ} \mathrm{C}$ with shaking, and resuspended in $10 \mathrm{~mm}$-phosphate-buffered saline (PBS; $\mathrm{pH} 7.4$ ). A sample of $50 \mu \mathrm{l}$ of bacterial suspension (about $10^{9}$ cells $\mathrm{ml}^{-1}$ ) was mixed with $50 \mu \mathrm{l}$ of a $1: 50$ dilution of the antiserum in a test tube. The mixture was incubated for $12 \mathrm{~h}$ at room temperature. Agglutination was determiend visually, using the bacterial suspension plus PBS alone as a control.

Haemagglutination test. The haemagglutinating activities of TAP13 cells and the purified pili were examined with human group $A$, rabbit and sheep erythrocytes. Equal volumes $(25 \mu \mathrm{l})$ of $2 \%(\mathrm{v} / \mathrm{v})$ washed erythrocytes and bacterial cells (about $10^{9}$ cells $\mathrm{ml}^{-1}$ in KRT buffer) or purified pili ( $300 \mu \mathrm{g} \mathrm{ml}^{-1}$ in KRT buffer) were mixed on a glass cavity slide. Agglutination was judged visually within $1 \mathrm{~min}$.

Adhesion test. The ability of the organisms to adhere to rabbit intestinal epithelium was examined by the MASK method (Nakasone \& Iwanaga, 1987), which we have used elsewhere (Nakasone \& Iwanaga, 1990; Hokama \& Iwanaga, 1991). Briefly, formalin-fixed intestine was incubated in the bacterial suspension (about $10^{9}$ cells $\mathrm{ml}^{-1}$ in $\mathrm{KRT}$ buffer) for $10 \mathrm{~min}$ at $30^{\circ} \mathrm{C}$, then vigorously washed with KRT buffer. The sample was prepared for scanning electron microscopy. Adherent organisms were counted in 10 randomly selected scanning electron microscope fields at $\times 4000$ magnification. The adhesion index was expressed as the mean number of adherent organisms per observation field of the intestinal epithelium.

Adhesion inhibition test. Two kinds of pretreatment were performed before the adhesion test as described previously (Nakasone \& Iwanaga, 1990; Hokama et al., 1990). Briefly, in the first method, the organisms (about $10^{9}$ cells $\mathrm{ml}^{-1}$ ) were preincubated with the Fab fraction of either nonimmunized rabbit IgG or antipilus antibody at $30^{\circ} \mathrm{C}$ for $30 \mathrm{~min}$ before they were reacted with the intestinal epithelium. The Fab fractions were used instead of intact antibody because intact antibody agglutinates the organisms. In the second method, intestinal epithelium pretreated in the purified pilus suspension at $30^{\circ} \mathrm{C}$ for $30 \mathrm{~min}$ was exposed to the intact organisms.

Preparation of antibody. Antipilus antisera were prepared by multiple subcutaneous injections of approximately $0.1 \mathrm{mg}$ of purified pili emulsified with Freund's adjuvant (Difco) into a Japanese White rabbit and by boosting every two weeks. Several days after each boost, blood was collected and the sera were pooled. Nonimmunized sera were obtained before the first injection. An IgG fraction of the sera was obtained by salting out the pooled sera with $33 \%$ saturated ammonium sulphate. The Fab fraction of the IgG was prepared by papain (Sigma) digestion and SP-Sephadex C-50 column chromatography (Pharmacia).

Amino acid sequence. The N-terminal amino acid sequence of the pilin was analysed by automated Edman degradation on a Shimadzu PSQ-1 protein sequencer.

Protein assay. The protein content was assayed by the Lowry method, with bovine serum albumin as the standard.

Statistical analysis. Data analysis was performed by the chi-square test and the Cochran-Cox test.

\section{Results}

\section{Morphological findings}

A. sobria TAP13 cells had a small number of long, flexible, wavy pili (designated TAP13 pili) with a diameter of about $7 \mathrm{~nm}$ (Fig. 1). TAP13 pili were morphologically indistinguishable from $A$. hydrophila Ae6 W pili (Hokama et al., 1990) and A. sobria Ael pili (Hokama \& Iwanaga, 1991).

\section{Purification of the pili}

The salted-out precipitates contained mainly pili and flagella. The flagella and other contaminants were removed by sucrose density-gradient ultracentrifugation. Fig. 2 shows the electron microscopic appearance of negatively stained, purified TAP13 pili. The purified pili had the same appearance as the pili seen on the cells. The molecular mass of the TAP13 pilin was estimated to be about $23 \mathrm{kDa}$, identical to that of Ael pilin and larger than that of Ae6 W pilin (21 kDa) (Fig. 3a). 


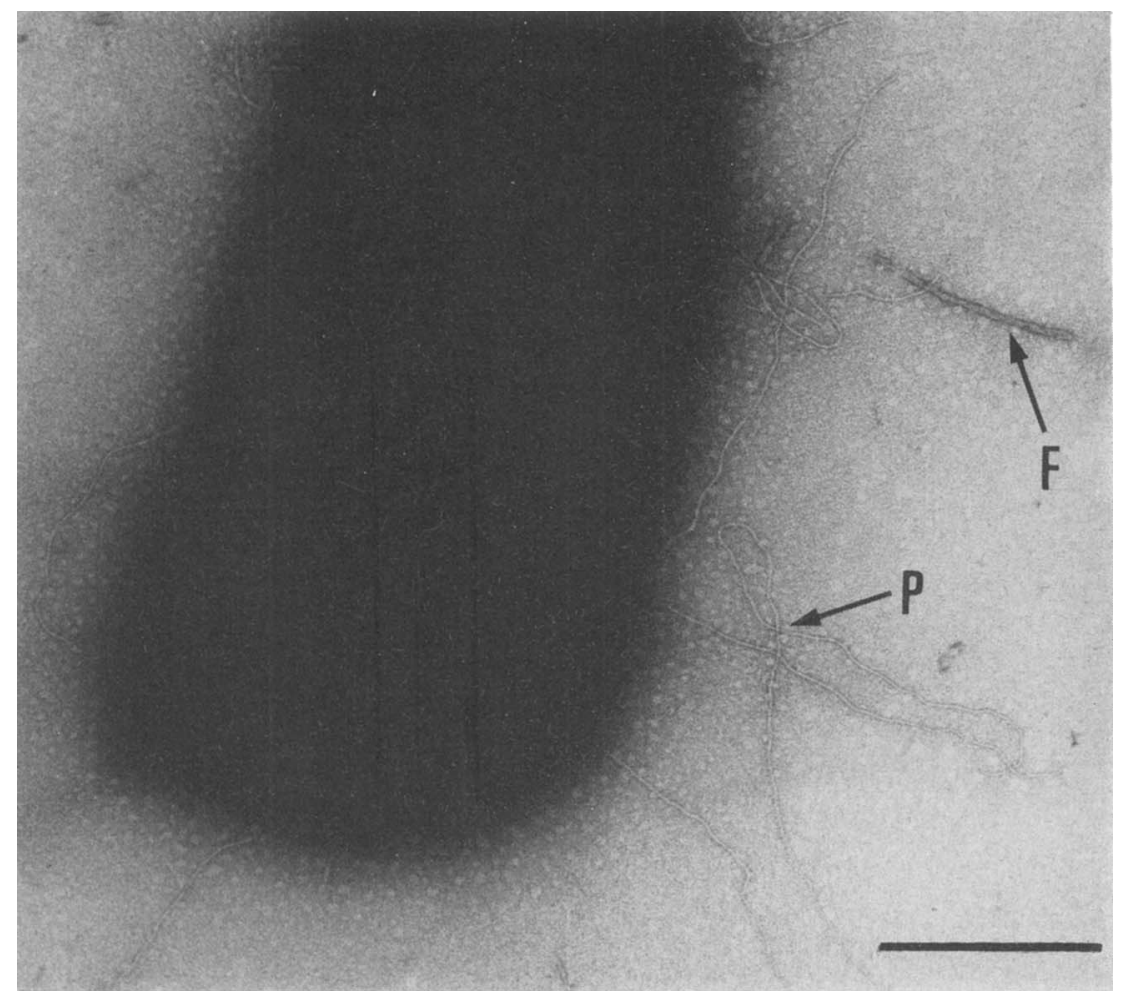

Fig. 1. Transmission electron micrograph of an A. sobria TAP13 cell, negatively stained with $4 \%$ uranyl acetate. Wavy, flexible pili are seen. $\mathrm{P}$, pilus; F, flagellum. Bar, $500 \mathrm{~nm}$.

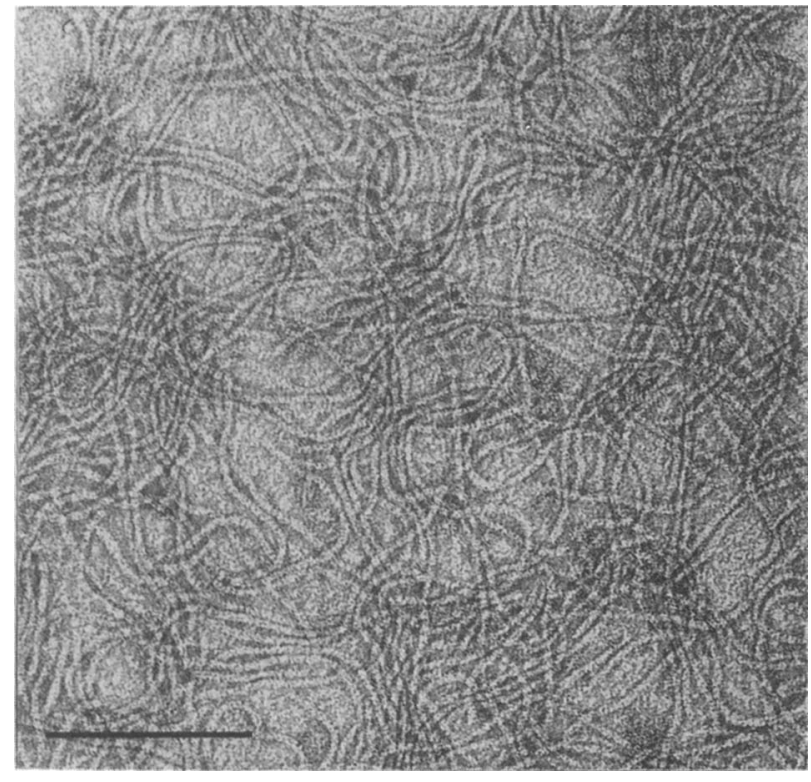

Fig. 2. Transmission electron micrograph of purified pili of $A$. sobria TAP13, negatively stained with $4 \%$ uranyl acetate. Wavy, flexible pili with a diameter of about $7 \mathrm{~nm}$ are seen. Bar, $200 \mathrm{~nm}$.

\section{Immunological studies}

Western blotting showed that TAP13 pilin, but not Ae1 or Ae6 W pilin, reacted with anti-TAP13 pilus antibody
(Fig. $3 b$ ). Nonimmunized serum, anti-Ael pilus antibody and anti-Ae6 $\mathrm{W}$ pilus antibody did not react with TAP13 pilin (data not shown). Specificity of anti-pilus antisera was also confirmed by immunogold staining, which showed gold particles only on the pili, not on the flagella or the bacterial surface (Fig. 4). Pili adherent to the rabbit intestinal epithelium were detected by using enzyme-labelled antibody (Fig. 5). The presence of pili was shown by brown colour development along the epithelial surface (Fig. $5 b$ ), which was absent on the control tissue (Fig. 5a).

The distribution of TAP13 pilus-related antigen in various strains of Aeromonas spp. is shown in Table 1. Eleven Aeromonas strains out of 98 examined (11\%) agglutinated with anti-TAP13 pilus antiserum. Clinical and environmental isolates of $A$. sobria showed positive agglutination in 3 out of 16 strains $(16 \%)$ and 0 out of 26 strains, respectively. The difference between the two detection rates was significant at $P=0.035$ (chi-square test). Among the 47 A. hydrophila strains, $15 \%$ of both clinical and environmental isolates showed agglutination.

\section{Haemagglutination}

TAP13 cells and purified pili did not agglutinate human group $\mathrm{A}$, rabbit or sheep erythrocytes. 
(a)

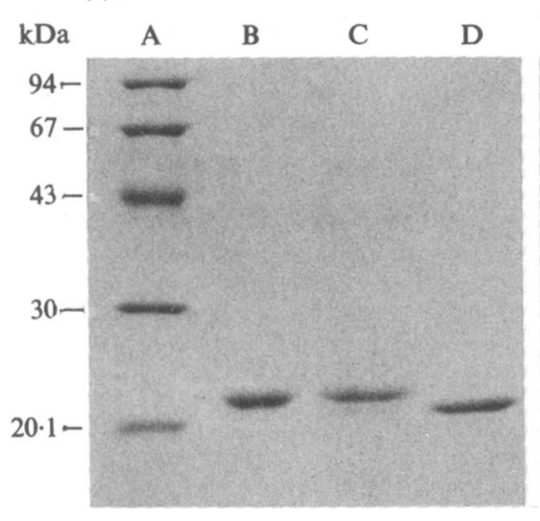

(b)

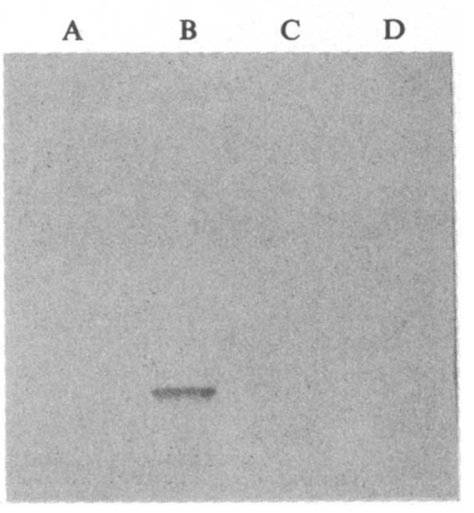

Fig. 3. (a) SDS-PAGE profile of purified Aeromonas pili. Lanes: A, molecular mass markers (Pharmacia); B, purified pili of A. sobria TAP13; C, purified pili of A. sobria Ae1; D, purified W pili of a. hydrophila Ae6. (b) Western blot of the proteins in the SDS-PAGE gel treated with anti-TAP13 pilus antibody. Only TAP13 pilin reacted.

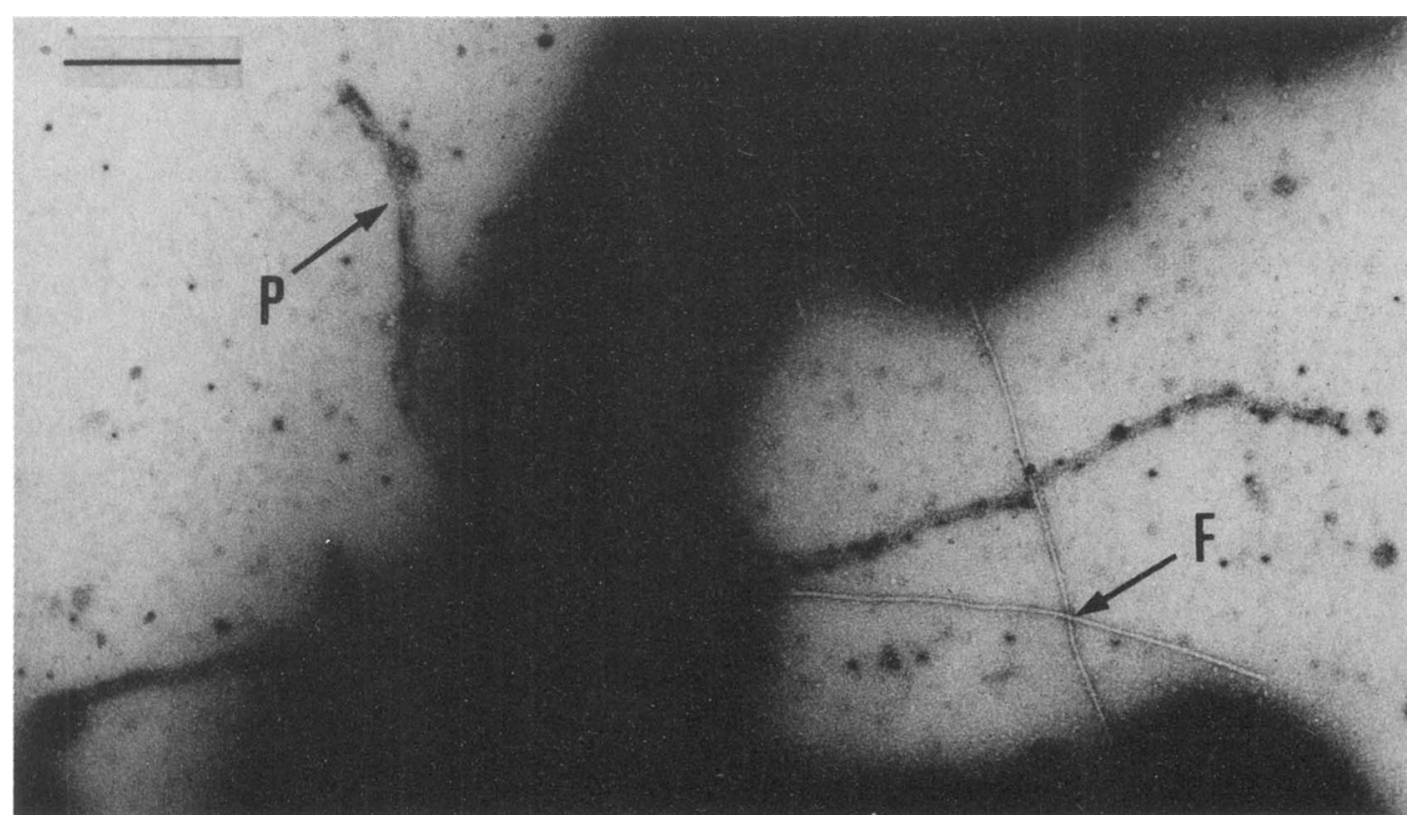

Fig. 4. Transmission electron micrograph of $A$. sobria TAP13 labelled by the immunogold technique. Cells were incubated with rabbit anti-TAP13 pilus antiserum and then with protein A conjugated with $15 \mathrm{~nm}$ colloidal gold particles. Labelled cells were negatively stained with $4 \%$ uranyl acetate. The gold particles bound specifically along the length of the pili. Note that pili reacting with the antibody appear distended. $P$, pilus; F, flagellum. Bar, $500 \mathrm{~nm}$.

\section{Adhesion and adhesion inhibition test}

TAP 13 cells had an adhesion index of approximately 70 for rabbit intestine as determined by the MASK method (Nakasone \& Iwanaga, 1987). Adhesion of the bacteria to rabbit intestinal villi is shown in Fig. 6. The adhesion index was markedly lowered by pretreating the intestine with purified pili $(P<0.001$; Cochran-Cox test) or by pretreating the organisms with the Fab fraction of the anti-pilus antibody $(P<0.001)$. The Fab fraction of nonimmunized rabbit $\mathrm{IgG}$ did not inhibit bacterial adhesion (Table 2).

\section{Amino acid sequence}

The N-terminal amino acid sequence of TAP13 pilin is shown in Table 3. Comparing it with the sequences of Ae6 W pilin and Ael pilin previously reported (Hokama 

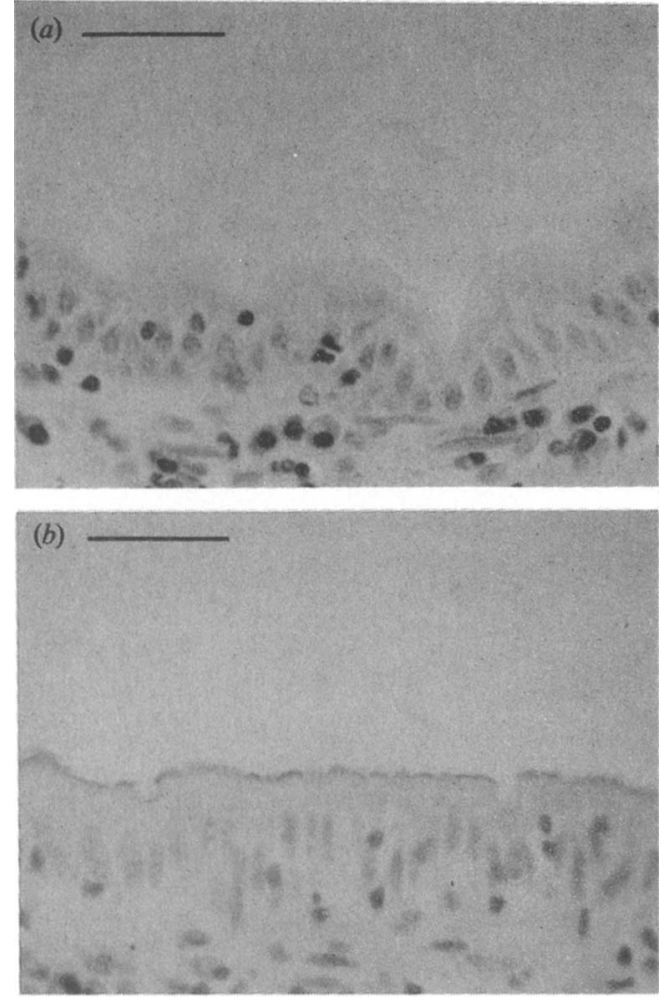

Fig. 5. Immunohistochemical detection of purified pili of $A$. sobria TAP13 adhering to rabbit intestinal villi. (a) Control intestine (only the pili were removed from the reaction procedure). The section with stained with Mayer's haematoxylin. (b) Adherence of TAP13 pili to the rabbit intestine detected by enzymic colouration along the villus surface. Bars, $30 \mu \mathrm{m}$.

Table 1. Distribution of strains immunologically crossreactive with anti-TAP13-pilus antibody

\begin{tabular}{lcc}
\hline \multicolumn{1}{c}{ Taxon } & No. examined & No. positive $(\%)$ \\
\hline A. sobria & 19 & $3(16)^{*}$ \\
$\quad$ Clinical & 26 & $0(0)$ \\
$\quad$ Environmental & & \\
A. hydrophila & 20 & $3(15)$ \\
$\quad$ Clinical & 27 & $4(15)$ \\
$\quad$ Environmental & & $1(17)$ \\
A. caviae & 6 & $11(11)$ \\
$\quad$ Clinical & 98 & \\
Total & 98 \\
\hline
\end{tabular}

* $P=0.035$ compared to the detection rate in A. sobria environmental isolates (statistics by chi-square test).

\& Iwanaga, 1991), there is $90 \%$ homology in the first 10 residues. The $\mathrm{N}$-terminal amino acid is tyrosine in TAP13 pilin, whereas it is methionine in the two previously reported pilins.

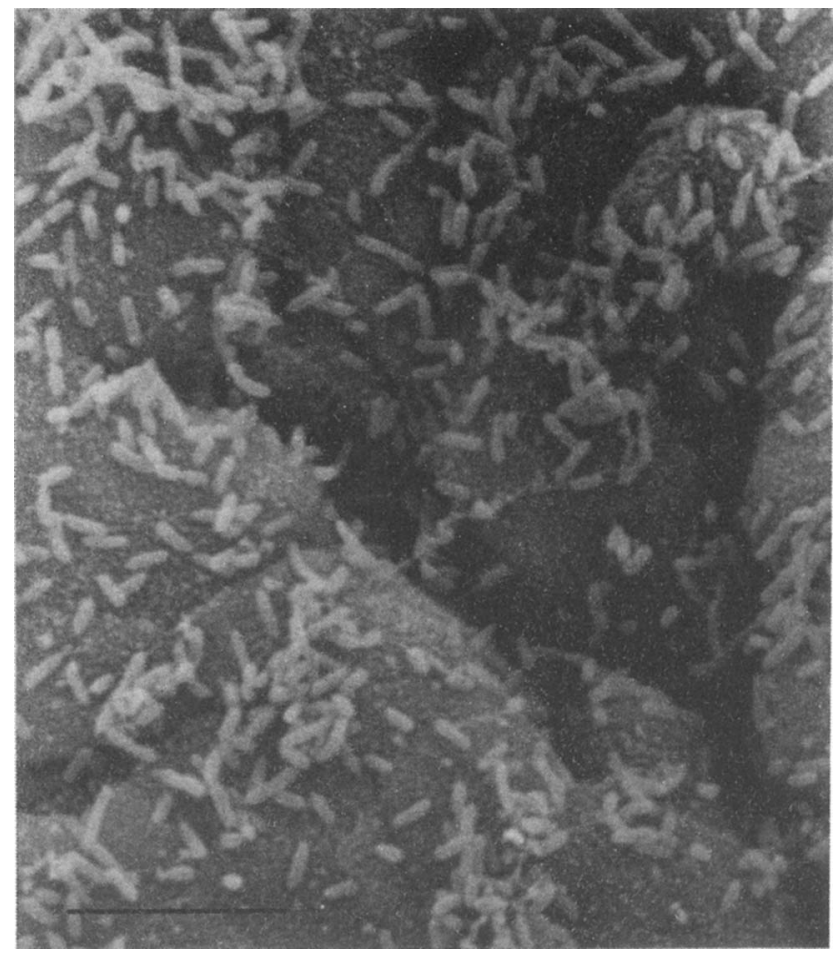

Fig. 6. Scanning electron micrograph of A. sobria TAP13 cells adhering to formalin-fixed rabbit intestinal villi. Bar, $10 \mu \mathrm{m}$.

Table 2. Adhesion and adhesion inhibition tests of A. sobria TAP13 cells to the rabbit intestinal epithelium

\begin{tabular}{ll}
\hline \hline Pretreatment of the intestine or organisms with: & $\begin{array}{c}\text { Adhesion } \\
\text { index }\end{array}$ \\
\hline Control $\dagger$ & $71 \pm 7$ \\
Purified pili $\left(600 \mu \mathrm{g} \mathrm{ml}^{-1}\right)$ & $19 \pm 3 \ddagger$ \\
Anti-pilus Fab $\left(3 \mathrm{mg} \mathrm{ml}^{-1}\right)$ & $11 \pm 2 \ddagger$ \\
Nonimmunized Fab $\left(3 \mathrm{mg} \mathrm{ml}^{-1}\right)$ & $79 \pm 8$ \\
\hline \hline
\end{tabular}

* Values are means \pm SEM for 10 determinations. The data are representative of three separate experiments.

t For the control, no pretreatment was performed before the reaction of the organisms and the rabbit intestine.

$\ddagger P<0.001$ compared with the control (statistics by Cochran-Cox test).

Table 3. N-terminal amino acid sequence of $A$. sobria TAP13 pilin

The sequences of $A$. sobria Ael pilin and $A$. hydrophila Ae6 W pilin (Hokama \& Iwanaga, 1990) are presented for comparison. Residues are presented in the one-letter code.

\begin{tabular}{ll}
\hline \multicolumn{1}{c}{ Pilin } & \multicolumn{1}{c}{ Sequence } \\
\hline A. sobria TAP13 & YTLIE LVIVI IILGI LA \\
A. sobria Ae1 & MTLIE LVIVI \\
A. hydrophila Ae6 W & MTLIE LVIVI \\
\hline \hline
\end{tabular}




\section{Discussion}

Various studies have been carried out to identify colonization factors produced by Aeromonas spp., and pilus and non-pilus colonization factors and haemagglutinins have been reported (Atkinson et al., 1987; Nandapalan \& Chang, 1989; Ho et al., 1990; Hokama et al., 1990; Hokama \& Iwanaga, 1991). Among six Aeromonas pili purified so far, we proved that $A$. sobria Ae1 pili and $A$. hydrophila Ae6 W pili were colonization factors for the intestines as well as being haemagglutinins. Ho et al. (1990) reported that $A$. hydrophila AH26 flexible pili acted as a haemagglutinin. These pili are classified into two morphological types, straight and flexible. The flexible pili (Ho et al., 1990; Hokama et al., 1990; Hokama \& Iwanaga, 1991) were haemagglutinative but the straight ones (Sato et al., 1989; Honma \& Nakasone, 1990; Ho et al., 1990) were not. The TAP13 pili studied here are unique, in being morphologically flexible but not haemagglutinative, yet nevertheless adhering to rabbit intestinal epithelium.

TAP13 pili were shown to be a colonization factor of A. sobria TAP13 by immunohistochemical study and adhesion inhibition tests. However, the bacterial adhesion to rabbit intestine was not completely inhibited by blocking pilus function with anti-pilus Fab or by blocking the epithelial receptors with the purified pili. This incomplete inhibition may have been due to insufficient amounts of these blocking agents being used. Another possibility is the presence of non-pilus colonization factors within this organism. Even if the organism had a non-pilus colonization factor, it would not be a haemagglutinin, because whole cells of TAP13 did not agglutinate erythrocytes.

The haemagglutinating ability of bacteria and isolated pili has been used as a useful screening model for detecting their adhesive ability (Atkinson \& Trust, 1980). Although most bacterial pilus colonization factors agglutinate erythrocytes, non-haemagglutinative colonization factors have occasionally been reported. Nakasone \& Iwanaga (1990) reported a non-haemagglutinative pilus colonization factor isolated from a Vibio parahaemolyticus strain, Teppema et al. (1987) reported one from a $V$. cholerae $\mathrm{Ol}$ strain, and Reyes $e t$ al. (1983) showed some $V$.parahaemolyticus strains in this category. In Aeromonas spp., Nishikawa et al. (1991) reported that a non-haemagglutinative $A$. sobria strain adhered to INT407 cells. Carrello et al. (1988) found that some Aeromonas strains adhered to HEp-2 cells without agglutinating human group $O$ erythrocytes and that some of them possessed (flexible) type L pili. Moreover, preliminary work has shown that most non-haemagglutinative Aeromonas isolates stocked in our laboratory have adhesive ability (data not shown). Therefore, it is not surprising that non-haemagglutinative $A$. sobria TAP13 pili play a role in intestinal adhesion. The relationship between haemagglutinating pattern and adhesion index requires further investigation.

Among 98 strains of Aeromonas spp. stocked in our laboratory, 52 reacted immunologically with either antiTAP13, anti-Ae1 or anti-Ae6 W pilus antibody. Whether all these 52 strains have the respective pili has not yet been determined. The other 46 strains, immunologically not reactive to the above antibodies, were also adhesive to the rabbit intestine (data not shown). Therefore, colonization factors for many Aeromonas strains have yet to be identified. Further work on the identification of Aeromonas pilus and non-pilus colonization factors is required.

\section{References}

Ascencio, F., LJUGH, $\AA . \&$ Wadström, T. (1991). New lectins and other putative adhesins in Aeromonas hydrophila. Experientia 47, 414-416.

AtKinson, H. M. \& Trust, T. J. (1980). Hemagglutination properties and adherence ability of Aeromonas hydrophila. Infection and Immunity 27, 938-946.

Atrinson, H. M., Adams, D., Savvas, R. S. \& Trust, T. J. (1987). Aeromonas adhesin antigens. Experientia 43, 372-374.

CaHILl, M. M. (1990). Virulence factors in motile Aeromonas species. Journal of Applied Bacteriology 69, 1-6.

Carrello, A., Silburn, K. A., Budden, J. R. \& Chang, B. J. (1988). Adhesion of clinical and environmental Aeromonas isolates to HEp-2 cells. Journal of Medical Microbiology 26, 19-27.

Daily, O. P., Joseph, S. W., CoOlbaugh, J. C., Waiker, R. I., Merrell, B. R., Rollins, D. M., Seidler, R. J., Colwell, R. R. \& LISSNER, C. R. (1981). Association of Aeromonas sobria with human infection. Journal of Clinical Microbiology 13, 769-777.

Gray, S. J., Stickler, D. J. \& BRYANT, T. N. (1990). The incidence of virulence factors in mesophilic Aeromonas species isolated from farm animals and their environment. Epidemiology and Infection 105, 277-294.

Ho, A. S. Y., Mietzner, T. A., Smith, A. J. \& Schoolnik, G. K. (1990). The pili of Aeromonas hydrophila: identification of an environmentally regulated 'mini pilin'. Journal of Experimental Medicine 172, 795-806.

Hokama, A. \& Iwanaga, M. (1991). Purification and characterization of Aeromonas sobria pili, a possible colonization factor. Infection and Immunity 59, 3478-3483.

Hokama, A., Honma, Y. \& Nakasone, N. (1990). Pili of an Aeromonas hydrophila strain as a possible colonization factor. Microbiology and Immunology 34, 901-915.

Honma, Y. \& Nakasone, N. (1990). Pili of Aeromonas hydrophila purification, characterization and biological role. Microbiology and Immunology 34, 83-98.

JANDA, J. M. (1991). Recent advances in the study of the taxonomy, pathogenicity, and infectious syndromes associated with the genus Aeromonas. Clinical Microbiology Reviews 4, 397-410.

KROGFELT, K. A. (1991). Bacterial adhesion: genetics, biogenesis, and role in pathogenesis of fimbrial adhesins of Escherichia coli. Reviews of Infectious Diseases 13, 721-735.

LAEMMLI, U. K. (1970). Cleavage of structural proteins during the assembly of the head of bacteriophage T4. Nature, London 227, 680-685.

MoYer, N. P. (1987). Clinical significance of Aeromonas species isolated from patients with diarrhea. Journal of Clinical Microbiology 25, 2044-2048. 
NAKASONE, N. \& IwANAGA, M. (1987). Quantitative evaluation of colonizing ability of Vibrio cholerae O1. Microbiology and Immunology 31, 753-761.

Nakasone, N. \& Iwanaga, M. (1990). Pili of a Vibrio parahaemolyticus strain as a possible colonization factor. Infection and Immunity $\mathbf{5 8}$, $61-69$.

Nandapalan, N. \& Chang, B. J. (1989). Production and characterization of monoclonal antibodies to Aeromonas sobria surface antigens. FEMS Microbiology Immunology 47, 515-524.

NishikaWA, Y., KimURA, T. \& KISHI, T. (1991). Mannose-resistant adhesion of motile Aeromonas to INT407 cells and the differences among isolates from humans, food and water. Epidemiology and Infection 107, 171-179.

Pazzaglia, G., Sack, R. B., Bourgeios, A. L., Froehlich, J. \& ECKSTEIN, J. (1990). Diarrhea and intestinal invasiveness of Aeromonas strains in the removable intestinal tie rabbit model. Infection and Immunity 58, 1924-1931.
Reyes, A. L., Crawford, R. G., Spaulding, P. L., Peeler, J. T. \& TWEDT, R. M. (1983). Hemagglutination and adhesiveness of epidemiologically distinct strains of Vibrio parahaemolyticus. Infection and Immunity 39, 721-725.

Sato, M., Arita, M., Honda, T. \& Miwatani, T. (1989). Characterization of a pilus produced by Aeromonas hydrophila. FEMS Microbiology Letters 59, 325-330.

Teppema, J. S., Guinee, P. A. M., Ibrahim, A. A., Paques, M. \& RUITEBERG, E. J. (1987). In vivo adherence and colonization of Vibrio cholerae strains that differ in hemagglutinating activity and motility. Infection and Immunity 55, 2093-2102.

Towbin, H., Staehelin, T. \& Gordon, J. (1979). Electrophoretic transfer of proteins from polyacrylamide gels to nitrocellulose sheets: procedure and some applications. Proceedings of the National Academy of Sciences of the United States of America 76, 43504354. 